\title{
Effect of a dam on epilithic algal communities of a mountain stream: before-after dam construction comparison
}

\author{
Luciana CIBILS MARTINA, ${ }^{*}$ Romina PRINCIPE, Noemí GARI \\ Departamento de Ciencias Naturales, Universidad Nacional de Río Cuarto (UNRC), Ruta 36, Km 601, 5800, Río Cuarto, Córdoba, \\ Argentina. \\ *Corresponding author: 1cibils@gmail.com
}

\begin{abstract}
In this study we evaluated the effect of a dam on epilithic algal communities by analyzing community response after dam construction and by comparing community composition, structure and biomass upstream and downstream of the dam. Samples of epilithic algae and environmental data were collected at each site during high and low water periods before and after dam construction in Achiras Stream (Córdoba, Argentina). Ordinations showed modifications in algal assemblages after dam construction and downstream of the dam. Ordinations also suggested a loss of seasonality at the downstream site since the assemblages were similar between hydrological periods after dam construction. Our results also pointed out that dam construction affected not only the assemblages living at downstream site but also those in the upstream site. Indicator species, obtained by the Indicator Value method, showed that, after dam construction, there could have been an increase in nutrient concentration and a release of plankton from the impoundment. Abundance, richness and diversity were altered after dam construction as assessed by ANOVAs derived from a modified BACI Design. The proportion of earlysuccessional species was higher at the upstream site while late-successional species were dominant at the downstream site, as predicted. Current velocity was higher in the high water period upstream of the dam, with no differences between hydrological periods at the downstream site. So, lower fluctuations in discharge downstream of the dam may have helped succession advance, whereas at the upstream site, mainly during the high water period, floods appear to have caused sloughing of life forms from the outer layers of the biofilm, resetting the algal community to early successional stages. It may be concluded that the dam affected algal community and favoured succession advance mainly by reducing current velocity and flow fluctuations.
\end{abstract}

Key words: periphyton, regulated streams, diatom morphological guilds, detector species, lotic ecosystem.

Received: April 2012. Accepted: June 2012.

\section{INTRODUCTION}

Rivers and streams around the world are used for different purposes, which makes the maintenance of their health of central importance for their functioning (Norris and Thoms, 1999). River continuity (Vannote et al., 1980) and patch dynamics (Townsend, 1989) are profoundly interrupted when dams are used to retain or divert the flow of water (Grubbs and Taylor, 2004; Hauer and Lorang, 2004). Dams are designed to store water and modify the magnitude and timing of its movement downstream. Although dams have had many advantages for industries and people (Brandt, 2000; Poff and Hart, 2002), numerous authors have reported that river regulation has a negative impact on the structure and function of lotic ecosystems (Hardwick et al., 1992; Kingsford, 2000; Magilligan et al., 2003; Uehlinger et al., 2003; Gomes Lopes et al., 2004; Magilligan and Nislow, 2005; Francoeur and Biggs, 2006; Nichols et al., 2006; Wu et al., 2010).

Dams affect natural flow modifying the magnitude of floods and the occurrence of scouring floods, reducing thereby seasonal variation and annual mean discharge. They modify erosion and deposition rates and water and nutrient availability on floodplains. Dams also alter stability and availability of substrate and riparian vegetation and reduce sediment-carrying capacity leading to a reduction of suspended sediments downstream. On the other hand, the upstream effects include inundation of floodplains and the formation of new lakeshore vegetation types (Brandt, 2000; Merritt and Cooper, 2000; Newcomb et al., 2001; Poff and Hart, 2002; Jakob et al., 2003; Magilligan et al., 2003; Uehlinger et al., 2003; Gomes Lopes et al., 2004; Magilligan and Nislow, 2005; Olden and Naiman, 2010).

In headwater streams floods act as a disturbance being an important component in the determination of benthic assemblages (Ward and Stanford, 1983a; Jakob et al., 2003). The absence of this disturbance in regulated rivers, in combination with altered physical and chemical conditions, leads to dramatic changes in biotic assemblages (Ward and Stanford, 1979). In general, biodiversity downstream of a dam tends to be lower than in natural streams because of a reduced temporal heterogeneity in flow and temperature regime (Ward and Stanford, 1983b; Jakob et al., 2003; Poff and Zimmerman, 2010). Dams may also 
lead to a loss of sensitive and endemic species, alterations in dominant taxa, reduction of abundance and increase of non-native species (Poff and Zimmerman, 2010). Also, surface-release reservoirs discharge planktonic organisms downstream which are very scanty at intermediate reaches (Ward and Stanford ,1983b).

Although many authors have investigated the effect of dams on freshwater communities (Hardwick et al., 1992; Corigliano, 1994; Kingsford, 2000; Jakob et al., 2003; Grubbs and Taylor, 2004; Thomson et al., 2005; Nichols et al., 2006; Vallania and Corigliano, 2007; Principe, 2010) less attention has been paid to the response of epilithic algae to river regulation (Growns and Growns, 2001; Uehlinger et al., 2003; Stenger-Kovács et al., 2006; Wu et al., 2010). Benthic algae support fluvial food webs (Stevenson and Bahls, 1999) and have been widely use for environmental monitoring as indicators of changes in freshwater ecosystems (Hill et al., 2001; Stevenson and Smol, 2002; Wunsam et al., 2002; Lobo et al., 2004; Griffith et al., 2005).

The main factors controlling periphyton biomass in rivers are light intensity, temperature, grazing, current velocity, substrate type and water chemistry (Allan and Castillo, 2007). Flow regime has been considered as a master variable limiting species distribution and abundance and regulating ecologic integrity of rivers and streams (Poff et al., 1997). Particularly, the response of the algal community to current velocity depends on the growth form and the assemblage architecture. Tightly adhering forms are less vulnerable to drag than loosely adhering forms, and they can be dependent on diffusion for material supplement, profiting with increases in current velocity (Francoeur and Biggs, 2006; Allan and Castillo, 2007). Many studies about regulated reaches have reported current velocity as a factor that explained changes in algal communities, affecting richness, biomass and community composition and structure (Growns, 1999; Wu et al., 2009, 2010; Uehlinger et al., 2003).

In this study we aimed to evaluate the effect of a dam on epilithic algal communities of a mountain stream by comparing the community response after dam construction with results before construction, and by analyzing community composition, structure and biomass upstream and downstream of the dam. Variations of some hydraulic, physical and chemical factors are also analyzed. Based on theory and empirical antecedents, we hypothesized that dams, by reducing current velocity and flow fluctuations, would alter epilithic algal community composition and structure and favor successional advance. Thus, the abundance of early-successional species was expected to be higher upstream of the dam, and late-successional species were expected to be more abundant downstream. Besides, species assemblages before dam construction were expected to be different from assemblages registered after the construction, especially in the downstream site, highlighting indicator species of the change. We also hypothesized that the algal community would not show differences between hydrological periods downstream of the dam either, because of its homogenizing effect, and a reduction in biodiversity is expected.

\section{METHODS}

\section{Study area}

The study was carried out in headwaters of Achirasdel Gato basin, Córdoba, Argentina. The Achiras-del Gato watershed is an endoreic drainage system that covers 750 $\mathrm{km}^{2}$ and flows $130 \mathrm{~km}$ from headwaters in Sierra de Comechingones to Tigre Muerto Wetlands (Fig. 1) (Degiovanni, 2005). Achiras Stream is a forth order stream with headwaters in mountainous regions where many small streams, permanent and temporary, join to form the main collector at foothills (Degiovanni, 2005). This stream is located between 810 and $753 \mathrm{~m}$ asl and its drainage area is between $33^{\circ} 09^{\prime} 19^{\prime \prime}-33^{\circ} 11^{\prime} 18^{\prime \prime} \mathrm{S}$ and

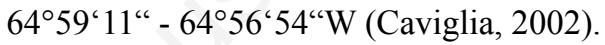

The hydrologic regime of Achiras stream is torrential with extreme flows concentrated in spring-summer season (from September to March) and with an average annual precipitation of $934 \mathrm{~mm}$. It is a permanent stream with low flows that range from 0.2 to $0.6 \mathrm{~m}^{3} \cdot \mathrm{s}^{-1}$, annual discharges of 10 to $20 \mathrm{~m}^{3} \cdot \mathrm{s}^{-1}$ and extraordinary flows of about $100 \mathrm{~m}^{3} \cdot \mathrm{s}^{-1}$ (Doffo et al., 2005). The maximum temperature reaches $34^{\circ} \mathrm{C}$ in summer (December-March) and decreases to $-5^{\circ} \mathrm{C}$ in winter (June-September). Riparian vegetation of the study area, which is only partially shaded, changes in relation to the longitudinal gradient and its distribution is modified by human activities (Luti et al., 1979). Some native species of downstream zones, such as Acacia caven (Mol.) Mol., Geoffroea decorticans (Gill.) Burk. and Celtis tala Planchon, also occur at this altitude along the stream banks and in the adjacent areas (Cabido et al., 2003). In some reaches there are also exotic species of ornamental trees and shrubs.

Two sites in the longitudinal gradient of Achiras Stream were selected: Site A, in natural mountainous area $1800 \mathrm{~m}$ upstream of a dam (control site) and Site B, located $2000 \mathrm{~m}$ downstream of the dam at foothills. The control site is located in a natural area used for some recreation activities during summer whereas agriculture and livestock are the dominant management activities in the site downstream of the dam. Construction of the dam was completed in 2007 with a reservoir capacity of 3.5 $\mathrm{Hm}^{3}$. The dam is $23.25 \mathrm{~m}$ high and $4.40 \mathrm{~m}$ wide. The objectives of its construction were: i) drinking water supply, ii) improvement of capacity of retention, regulation and evacuation of spates, and iii) tourist use of reservoir (DIPAS, 2001). Biological samples and environmental 
data were collected at each site during high (April) and low (September) water hydrological periods in 2006 and 2009 which correspond to before and after dam construction, respectively. Thus, sampling design was based on a modified Before-After-Control-Impact design (BACI; Underwood, 1994) for assessment of disturbance.

\section{Field and laboratory methods}

In each sampling occasion hydraulic and physicochemical variables were recorded. Water and air temperature, $\mathrm{pH}$ and conductivity were recorded with portable sensors. Depth and current velocity were measured with a Global Flow Probe at three equidistant points on a transect along stream width. Water samples were collected in 2009 for chemical analysis in the laboratory (total dissolved solids, salinity, hardness, alkalinity and nutrients).

Benthic algae samples were collected from three randomly selected rocks at each site in each year and hydrological period. Rock surfaces $\left(100 \mathrm{~cm}^{2}\right.$ average) were scrubbed with a brush in a recipient with clean water. The resultant material collected in 2006 (before dam construction) was fixed with $4 \%$ formalin and was used for species identification and density calculations. Samples collected in 2009 (after dam construction) were kept refrigerated in darkness and in the laboratory they were homogenized

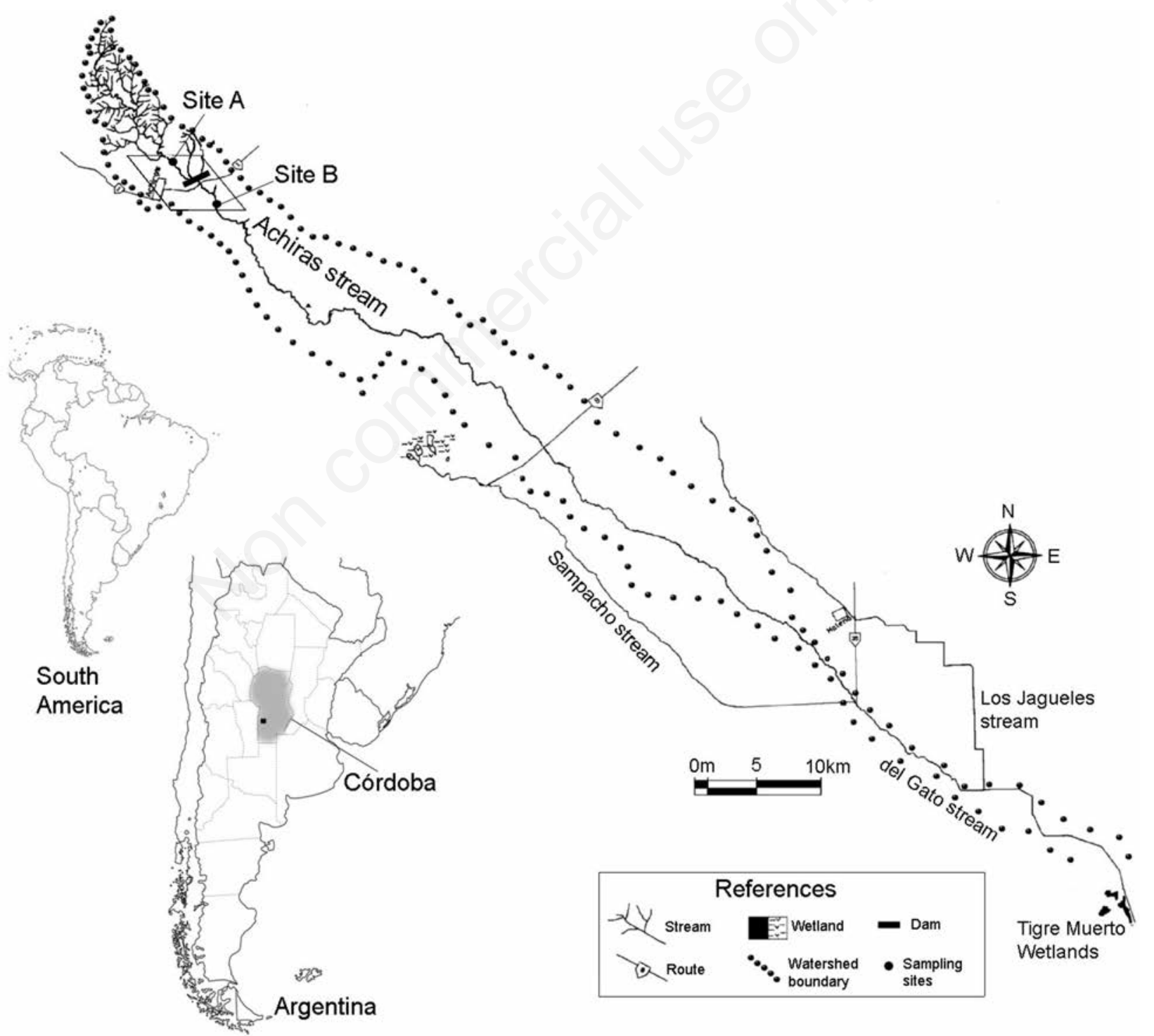

Fig. 1. Location of sampling sites in Achiras-del Gato Basin (Córdoba, Argentina) (modified from Caviglia, 2002). 
and fractionated in three subsamples. One aliquot was fixed with $4 \%$ formalin and was used for species identification and density calculations. Besides, diatom species were assigned to morphological guilds following Molloy (1992) and Kawamura and Hirano (1992) (Tab. 1). Another fraction was filtered through a glass-fiber filter $\mathrm{GF} / \mathrm{C}$ to obtain ash-free dry mass (AFDM), and the third fraction was used to extract and quantify chlorophyll $a$ (chl $a$ ) by spectrophotometry (Nusch, 1980). Results were corrected by surface of inorganic substrate (Biggs and Kilroy, 2000).

For species identification, a Zeiss optic microscope was used. For diatom analysis, organic matter was previously eliminated following Battarbee (1986) method and permanent slides were prepared according to Hasle (1978), using ZRAX $(1,7)^{\circledR}$ as slide mounting medium. For taxonomic analysis, specific bibliography of each particular group was used and diatom names were updated following Stoermer et al. (1999). The counts were performed by direct methods at $400 \times$ magnification with slide and coverslip of $24 \times 50$ $\mathrm{mm}$ following transects along the coverslip. For each sample three subsamples were counted. The counting unit was the individual (cell, coenobium or colony) and for filamentous algae a $10 \mu \mathrm{m}$ length was counted as a single cell (Hill et al., 2000). Algal density estimation was based on Villafañe and Reid (1995).

The indicator species obtained by the Indicator Value Method (IndVal) were classified according to their habitat preferences in terms of some environmental variables and life forms. The categories to which algal species were assigned -based on $\mathrm{pH}$, conductivity, trophic state of the water body, current velocity, life form and salt content that can tolerate- were based on Oliva Martínez et al. (2005). The characteristics of the species to be allocated to each category were taken from Hustedt (1930), Patrick and Reimer (1966), Fore and Grafe (2002), Oliva Martínez et al. (2005), Lane and Brown (2007).

\section{Data analyses}

Data from 2006 (before dam construction) were compared with 2009 results, by ordinations, Multiresponse Permutation Procedure (MRPP), Indicator Value method (IndVal) and three-way Analyses of Variance (ANOVA). To evaluate changes in algal assemblages due to dam construction, a detrended correspondence analysis (DCA) was performed using CANOCO 4.5 (ter Braak and Šmilauer, 1997, 1998). Density values were ln $(\mathrm{x}+1)$ transformed to stabilize the variance. A MRPP (Biondini et al., 1988; McCune and Grace, 2002) was used to test the significance of the differences among groups and indicator taxa were obtained using the IndVal method (IndVal; Dufrêne and Legendre, 1997).

Good indicator species are those that are always present at sites in a given group and never occur in other groups. The indicator value ranges from 0 to 100 , which correspond to a perfect indication. Significance of each taxa was tested using Monte Carlo test with 1000 permutations. The species with significant $(\mathrm{P}<0.05)$ indicator value greater than $70 \%$ were considered indicators of each site before and after dam construction. Those species combined high specificity (present only in a particular time) and high fidelity (abundant in all samples of a time). Species with other combinations of specificity and fidelity, however, may also be useful indicators, e.g. detector species. When monitoring environmental change, species that span a range of ecological states may be more useful indicators of the direction of the change than highly specific species restricted to a single state. Thus, detector

Tab. 1. Diatom guilds assignment based on morphological characters and attachment forms. Adapted from Molloy (1992) and Kawamura and Hirano (1992).

\begin{tabular}{|c|c|}
\hline Guild & Morphological characters \\
\hline Achnanthes spp. & $\begin{array}{l}\text { Small in size; monoraphid; generally, prostrate orientation to the substrate. Achnantheiopsis, Achnanthes, Achnanthidium, } \\
\text { Karayevia, Planothidium, Psammothidium, Rossithidium }\end{array}$ \\
\hline Cocconeis spp. & $\begin{array}{l}\text { Concave monoraphid; prostrate orientation to substrate and large amounts of mucilage combine to give this taxon a unique } \\
\text { mode of adherence. Slow movement }\end{array}$ \\
\hline Centric & Cyclotella spp. \\
\hline Filamentous & Centric diatoms forming chains. Melosira y Aulacoseira \\
\hline Adnate & Adjacent to substrate surface without being prostrate or erect. Amphora, Epithemia, Rhopalodia, Denticula \\
\hline Erect & $\begin{array}{l}\text { Perpendicular to substrate without stalks, standing upright on the substratum. Some of them form rosettes, fans, or band or } \\
\text { zig-zag colonies. Solitary or colonial. Generally araphid or pseudoraphid. Fragilaria, Diatoma, Synedra, Pseudostaurosira }\end{array}$ \\
\hline Biraphid & $\begin{array}{l}\text { Biraphid, generally prostrate, frequently motile, swift gliding movement. Amphipleura, Craticula, Cymatopleura, Diploneis, } \\
\text { Geissleria, Gyrosigma, Hippodonta, Luticola, Navicula, Neidium, Nitzschia, Pinnularia, Placoneis, Sellaphora, Stauroneis, } \\
\text { Surirella }\end{array}$ \\
\hline Stalked & $\begin{array}{l}\text { Arborescent colony or stalk-forming genera, attached by mucilage. Cymbella, Encyonema, Encyonopsis, Gomphonema, } \\
\text { Hantzschia, Reimeria, Rhoicosphenia }\end{array}$ \\
\hline
\end{tabular}


species will provide information complementary to that provided by indicator species (McGeoch et al., 2002).

Species that were predicted to act as detectors of the change produced by the dam were those with indicator values between 5 and $<50 \%$ before the construction, and between 50 and $70 \%$ after dam construction for each site. Species meeting these criteria were regarded as sufficiently indicative of the environment conditions after the dam so as to reveal the change from the features before the dam to the current condition. Simultaneously, these species were judged as sufficiently uncharacteristic of the conditions before the dam so as to potentially show an increase in the indicator value under disturbances caused by the dam. The rationale for selecting potential detector species in this way is that those species with some degree of habitat preference are likely to move to adjacent habitats more rapidly under changing habitat conditions than generalist species and species characteristic of one or another site. The species predicted to act as detectors must be tested in the future, expecting an increase in their indicator values in coming years if the disturbance caused by the dam increases. IndVal and MRPP were carried out using PC-ORD version 5.0 (McCune and Mefford, 1999).

Structural attributes of community were calculated (total abundance, richness, diversity and evenness) and were compared with three-way ANOVAs that considered: Time effect (before and after dam construction), Site effect (sites A: upstream and B: downstream) and Period effect (low and high water). To meet the assumptions of normality and homocedasticity, total abundance data were $\ln$ transformed, and diversity and evenness indices were square root transformed. Student-Newman-Keuls (SNK) test was used for a posteriori comparisons. According to Underwood (1994), there is an effect of dam when the Time*Site*Period interaction is significant. This means that natural differences in structural variables between sites upstream and downstream of the dam are altered by dam construction and that the pattern of variation is modified by the hydrological period. If this interaction is not significant, consideration should be given to the Time*Site interaction, indicating that the differences in structural variables between upstream and downstream sites before dam construction vary after the dam construction. If this interaction is not significant single effect of the Time factor should be considered, as it indicates differences in structural variables before and after dam construction on the entire stream segment. ANOVAs were carried out using InfoStat (Di Rienzo et al., 2011).

In order to test the homogenizing effect of the dam on epilithic algae, a correspondence analysis (CA) was performed with samples of the downstream site, before and after dam construction. Additionally, a CA was performed to determine differences in algal assemblages between sites (upstream and downstream of the dam) after dam construction. The density data obtained during low and high water periods of 2009 were used. Rare species were excluded and density values were $\log (\mathrm{x}+1)$ transformed to stabilize the variance. A MRPP was used to examine diferences in community composition between sites and hydrological periods and indicator taxa for each site were obtained using the IndVal method.

Proportional abundance of diatom morphological guilds at each site (upstream and downstream of the dam) in the different hydrological periods was compared by two-way ANOVAs. The characterization of the algal community at each site after dam construction was performed through species richness, total abundance, biomass (chl$a$ and AFDM) and Shannon-Wiener diversity and evenness indices. Two-way ANOVAs were used to compare these community attributes between sites (upstream and downstream of the dam) and hydrological periods. To meet the assumptions of normality and homocedasticity, total abundance data were square root transformed. Finally, an ANOVA was performed to compare current velocity between sites after dam construction. SNK test was used for a posteriori comparisons in all cases.

\section{RESULTS}

\section{Comparison before and after dam construction}

In samples collected before and after dam construction at upstream and downstream sites of the dam, 274 taxa of benthic algae were identified, belonging to Ochrophyta (68\%), Chlorophyta (20\%), Charophyta (6\%), Cyanobacteria (5\%) and Euglenozoa (1\%) (Cavalier-Smith, 1998; Lewis and McCourt, 2004).

The DCA performed with samples taken before and after dam construction to evaluate changes in algal assemblages showed segregation of samples along both axes. The first axis of DCA (Eigenvalues, Axis1: 0.413; Axis 2: 0.240 ; Axis 3: 0.123; Axis 4: 0.057 and $36 \%$ of accumulated variance) showed a differentiation of the assemblages found before and after dam construction (Fig. 2), being these differences significant according to the MRPP $(\mathrm{P}=0.019)$. On the other hand, axis 2 separated assemblages present at each site (upstream and downstream of the dam).

Indicator species for each site before and after dam construction, and detector species were obtained using the IndVal method. Before dam construction, Navicula salinarum was the only indicator species, while after dam construction 13 species were selected as indicators being Karayevia clevei, Navicula cryptocephala var. veneta, Cocconeis pediculus and Psammothidium abundans fo. rosenstockii the ones with higher indicator values (Tab. 2). N. salinarum prefers brackish water or freshwater with high mineral content, whereas indicator species after dam construction prefer water with high mineral content and high $\mathrm{pH}$ values 
(alkaliphilous). C. pediculus and Nitzschia palea are tolerant to moderate levels of organic pollution and some of the indicator species are planktonic, such as Chroococcus sp. and Monoraphidium arcuatum.

Detector species of the change produced by the dam at each site are enumerated in Tab. 3. Reimeria uniseriata presented a marked increase $(52 \%)$ in its indicator value at upstream site after dam construction, whereas at downstream site Epithemia sorex showed the greatest change $(49 \%)$ in its indicator value.

ANOVAs performed to evaluate dam effect considering structural attributes of the communities before and after dam construction at each site (upstream and downstream of the dam) and in the two hydrological periods (high and low water) revealed changes in total abundance $(\mathrm{P}=0.0003)$ and richness $(\mathrm{P}=0.02)$. The maximum value of total abundance was registered at the downstream site before dam construction, whereas the minimum value was found after dam construction in the same site and hydrological period (Fig. 3). Richness was higher at the downstream site in the high water period after dam construction. A single effect of the time was detected on Shannon-Wiener diversity that increased after dam construction $(\mathrm{P}=0.01)$, while evenness did not show any significant differences $(\mathrm{P}>0.05)$.

The CA that considered only samples collected at the downstream site showed a clear separation between assemblages present before and after dam construction (Eigenvalues, Axis $1=0.679$; Axis $2=0.502$; Axis $3=0.364$; Axis $4=0.271$ and $81.4 \%$ of accumulated variance) (Fig. 4 ); the $\mathrm{CA}$ also detected a strong difference between hydrological periods in assemblages present before dam construction.

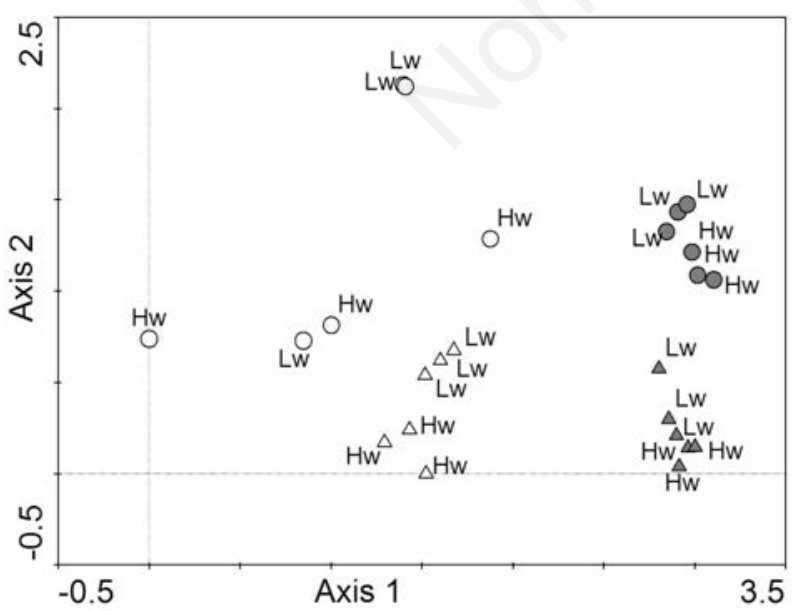

Fig. 2. DCA of periphyton samples (216 species) taken before (open symbols) and after (filled symbols) dam construction at upstream (circles) and downstream (triangles) sites in high (Hw) and low water $(\mathrm{Lw})$ periods.

\section{Upstream-downstream comparisons after dam construction}

Water chemical analysis of samples taken in 2009 (after dam construction) showed that some nutrients such as total dissolved solids, bicarbonates, sodium, potassium, calcium, magnesium and nitrates, as well as the conductivity were higher at the downstream site (Tab. 4). Current velocity was higher in the high water period upstream of the dam, as assessed by ANOVA ( $\mathrm{P}=0.012)$, with no differences between hydrological periods at the downstream site $\mathrm{B}$. The $\mathrm{pH}$ was slightly higher upstream. Water and air temperature was higher in the high water period in both sites, while depth was higher in the low water period (Tab. 4).

The CA performed with samples taken in 2009 revealed a clear separation of the assemblages present at each site (Eigenvalues, Axis $1=0.293$; Axis $2=0.170$; Axis $3=0.155$; Axis $4=0.059$ and $72.1 \%$ of accumulated variance) (Fig. 5). Axis 1 separated samples corresponding to each site whereas axis 2 separated samples from the different hydrological periods. This separation was stronger between samples taken upstream of the dam. MRPP analysis agrees with CA since it indicated significant differences in algal community composition between upstream and downstream sites $(\mathrm{P}=0.008)$.

Sites upstream and downstream of the dam were characterized by different sets of indicator taxa obtained by the IndVal method (Tab. 5). Upstream of the dam 13 indicator species were identified. The indicator taxa with the highest indicator values were Epithemia turgida, Epithemia sorex and Gomphonema dichotomum. In the downstream site, 22 indicator species were detected, those with higher indicator values being Gyrosigma obtusatum, Pinnularia silviasalae, Sellaphora pupula and Navicula gregaria. Indicator species of site A are widely distributed periphytic species with different degrees of tolerance to alkalinity (from $\mathrm{pH}$ indifferent to alkaliphilous) and salt concentration (from indifferent to oligohalobe) (Tab. 5). Indicator species of site $\mathrm{B}$ are tolerant to a wide range of conditions, some of them are indifferent to $\mathrm{pH}$ or alkaliphilous and others prefer high levels of salt in water (oligohalobe). Some species thrive in waters enriched with nutrients, particularly in sewages and wastewaters derived from agriculture and livestock, such as Gomphonema parvulum, Scenedesmus quadricauda and Nitzschia amphibia. Other indicator species of this site are characteristic of lentic environments, for instance Achnanthidium exiguum, Amphora ovalis var. affinis and Neidium affine.

Analysis of morphological guilds revealed a prevalence of Cocconeis spp. in site A during the high water pe$\operatorname{riod}(\mathrm{P}<0.0001$, Fig. 6) while erect forms predominated in the low water period $(\mathrm{P}=0.0048)$. In site $\mathrm{B}$, a predominance of Achnanthes spp. $(\mathrm{P}=0.0174)$ and biraphidal forms 
Tab. 2. List of indicator taxa before and after dam construction. Taxa with a significant $(\mathrm{P}<0.05)$ indicator value $(\mathrm{IV})>70 \%$ were selected as indicator.

\begin{tabular}{llc}
\hline & Taxa & IV \\
\hline Before dam construction & Navicula salinarum Grun. & 74.1 \\
\hline After dam construction & Karayevia clevei (Grun.) Bukht. & 100.0 \\
& Navicula cryptocephala var. veneta (Kütz.) Rabenh. & 100.0 \\
& Cocconeis pediculus Ehrenb. & 100.0 \\
& Psammothidium abundans fo. rosenstockii (Lange-Bert.) Bukht. & 100.0 \\
& Chrooccoccus sp. & 99.7 \\
& Amphora perpusilla Grun. & 87.3 \\
& Planothidium lanceolatum (Bréb.) Round and Bukht. & 87.0 \\
& Nitzschia palea (Kütz.) W.Sm. & 85.2 \\
& Nitzschia denticula Grun. & 83.3 \\
& Amphipleura lindheimeri Grun. & 83.0 \\
& Synedra ulna (Nitzsch) Ehrenb. & 81.4 \\
& Gomphonema dichotomum Kütz. & 75.0 \\
& Monoraphidium arcuatum (Korshikov) Hindák & 71.8 \\
\hline
\end{tabular}

Tab. 3. Detector taxa of the change after dam construction for sites upstream (A) and downstream (B) of the dam. Taxa with an indicator value (IV) between $5-50 \%$ before dam construction and between $50-70 \%$ after dam construction were selected as detectors.

\begin{tabular}{lcc}
\hline Site A & IV before & IV after \\
\hline Encyonema minutum (Hilse) D.G. Mann & 25 & 50 \\
Melosira varians C. Agardh & 12 & 63 \\
Reimeria uniseriata Sala et al. & 16 & 68 \\
\hline Site B & IV before & IV after \\
\hline Epithemia sorex Kütz. & 10 & 59 \\
Navicula capitatoradiata Germain & 23 & 54 \\
Nitzschia sinuata var. tabellaria (Grun.) Grun. & 15 & 55 \\
Reimeria uniseriata Sala et al. & 41 & 59 \\
Rhoicosphenia curvata Kütz.) Grun. & 31 & 63 \\
Monoraphidium arcuatum (Korshikov) Hindák & 22 & 56 \\
\hline
\end{tabular}

Tab. 4. Physicochemical and hydraulic variables recorded to characterize upstream (Site A) and downstream (Site B) sites in high water and low water periods of 2009.

\begin{tabular}{|c|c|c|c|c|}
\hline \multirow[b]{2}{*}{ Variables } & \multicolumn{2}{|c|}{ Site A } & \multicolumn{2}{|c|}{ Site B } \\
\hline & High water & Low water & High water & Low water \\
\hline TDS (mg.L $\left.\mathrm{L}^{-1}\right)$ & 173.00 & 198.00 & 399.00 & 409.00 \\
\hline $\mathrm{CO}_{3}\left(\mathrm{mg} \cdot \mathrm{L}^{-1}\right)$ & 0.00 & 0.00 & 0.00 & 0.00 \\
\hline $\mathrm{HCO}_{3}\left(\mathrm{mg} \cdot \mathrm{L}^{-1}\right)$ & 100.00 & 100.00 & 312.50 & 225.00 \\
\hline $\mathrm{S}\left(\mathrm{mg} \cdot \mathrm{L}^{-1}\right)$ & 20.50 & 33.40 & 27.50 & 43.70 \\
\hline $\mathrm{Cl}\left(\mathrm{mg} \cdot \mathrm{L}^{-1}\right)$ & 5.70 & 8.60 & 8.60 & 8.60 \\
\hline $\mathrm{Na}\left(\mathrm{mg} \cdot \mathrm{L}^{-1}\right)$ & 10.10 & 10.10 & 71.80 & 56.60 \\
\hline $\mathrm{K}\left(\mathrm{mg} \cdot \mathrm{L}^{-1}\right)$ & 2.20 & 3.80 & 5.00 & 5.30 \\
\hline $\mathrm{Ca}\left(\mathrm{mg} \cdot \mathrm{L}^{-1}\right)$ & 19.20 & 31.20 & 50.40 & 52.00 \\
\hline $\operatorname{Mg}\left(\mathrm{mg} . \mathrm{L}^{-1}\right)$ & 7.80 & 6.80 & 10.70 & 9.60 \\
\hline Nitrate $\left(\mathrm{mg} . \mathrm{L}^{-1}\right)$ & 6.60 & 3.00 & 15.50 & 7.50 \\
\hline Nitrite $\left(m g . L^{-1}\right)$ & 0.00 & 0.00 & 0.00 & 0.00 \\
\hline Fluoride (mg.L $\left.\mathrm{L}^{-1}\right)$ & 0.70 & 0.70 & 1.10 & 1.00 \\
\hline Arsenic (mg.L $\left.\mathrm{L}^{-1}\right)$ & 1.00 & 1.00 & 2.00 & 1.00 \\
\hline Total hardness (meq. $\mathrm{L}^{-1}$ ) & 1.60 & 2.10 & 3.40 & 3.40 \\
\hline T water $\left({ }^{\circ} \mathrm{C}\right)$ & 21.50 & 14.00 & 17.00 & 13.40 \\
\hline $\mathrm{T}$ air $\left({ }^{\circ} \mathrm{C}\right)$ & 27.90 & 18.60 & 22.00 & 9.40 \\
\hline $\mathrm{pH}$ & 8.68 & 8.85 & 7.98 & 7.81 \\
\hline Conductivity $\left(\mu \mathrm{S} . \mathrm{cm}^{-1}\right)$ & 199.61 & 284.54 & 524.30 & 620.74 \\
\hline Channel width (m) & 2.93 & 3.50 & 4.40 & 6.30 \\
\hline Mean depth (m) & 0.11 & 0.17 & 0.11 & 0.29 \\
\hline Mean current velocity $\left(\mathrm{m} \cdot \mathrm{s}^{-1}\right)^{*}$ & 0.17 & 0.09 & 0.10 & 0.08 \\
\hline
\end{tabular}

${ }^{*}$ Variation in current velocity by effect of the dam were assessed by two-way ANOVA. 
$(\mathrm{P}<0.0001)$ was observed in the high water period, while during the low water period a predominance of the stalked guild was recorded $(\mathrm{P}=0.0081)$.

Two-way ANOVAs showed changes in the structure of algal community downstream of the dam since abundance, richness and diversity were altered. Total abundance was higher at the upstream site in the low water period $(\mathrm{P}<0.0001$, Fig. 7) and the lowest value was observed downstream of the dam in the same period. AFDM only presented differences between hydrological periods $(\mathrm{P}=0.01)$, being the greatest in the low water period; $\mathrm{Chl} a$ did not show differences between either sites or periods $(\mathrm{P}>0.05)$. Richness was highest at the downstream site during the high water period ( $\mathrm{P}=0.0001$, Fig. 7); similarly, Shannon-Wiener diversity and evenness indices were greater at the same site and period $(\mathrm{P}<0.0001)$.

\section{DISCUSSION}

The findings of this study showed that the dam affected algal community composition and structure. As- semblages were markedly different before and after dam construction according to DCA. Although the reaches studied show natural geomorphologic differences that could have masked the dam effect or avoided its detection, the differences between samples taken before and after dam construction showed how natural variations between sites were modified over time. Similarly, Wu et al. (2009) observed that algal assemblages in downstream sites of the dam were similar to those of upstream control sites before dam construction and for one year after dam construction; however, assemblages were markedly different during the second and the third year after dam construction. Our results also pointed out that dam construction affected not only the assemblages living at downstream site but also those in the upstream site, similar to the findings reported by Principe (2010). In relation to this, it has been shown that important geomorphologic changes can occur upstream of low-head dams (Evans et al., 2007) with inundation of floodplains and the formation of new lakeshore vegetation types (Merritt and Cooper, 2000; Magilligan et al., 2003).

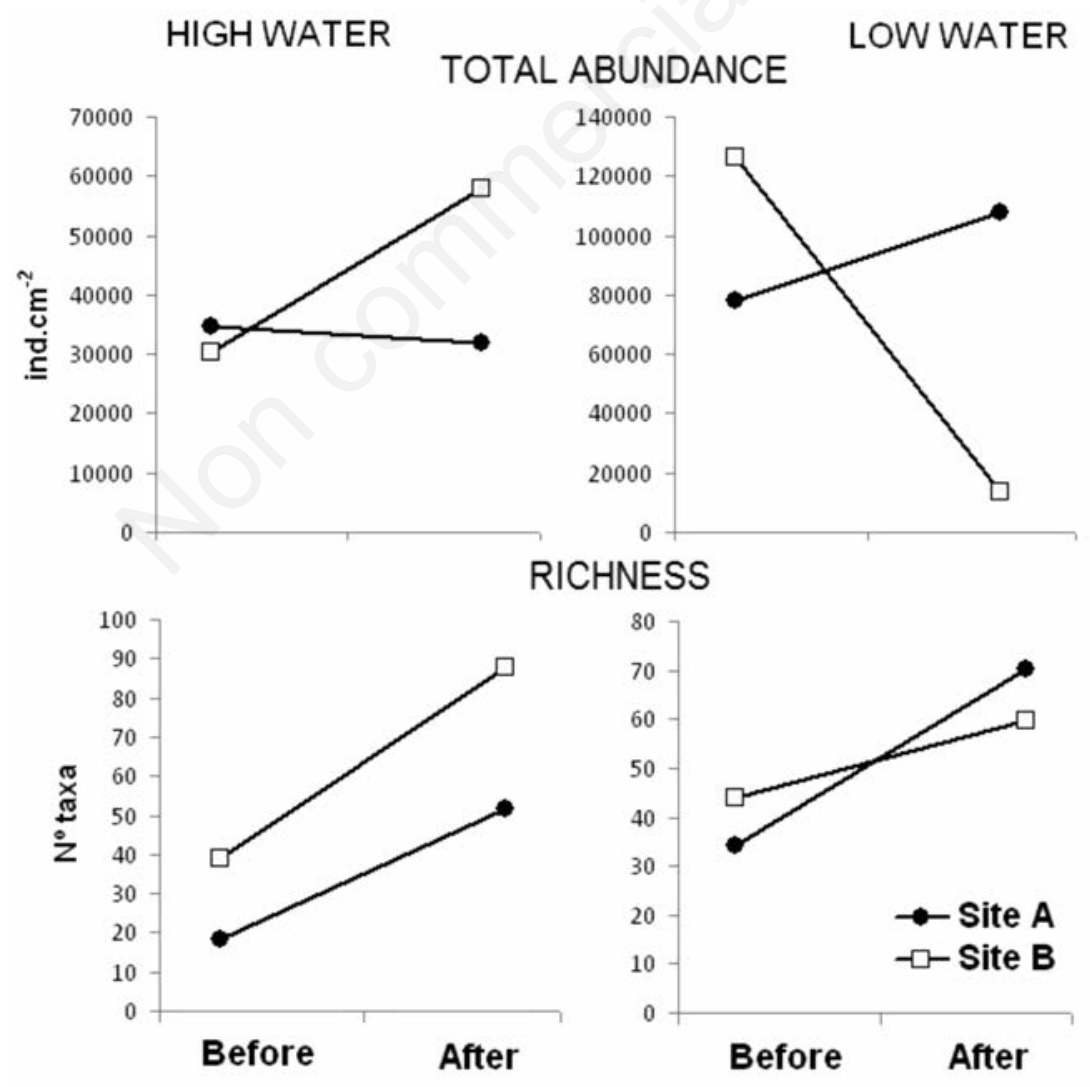

Fig. 3. Variation of structural attributes recorded before and after dam construction (2006 and 2009) in sampling sites upstream (A) and downstream (B) of the dam during two hydrological periods (high and low water). Only variables evidencing an effect of the dam are plotted (significant three-way interaction of ANOVAs). 
Indicator species showed that after dam construction there could have been an increase in nutrient concentration and a release of plankton from the impoundment. Detector species indicated possible habitat alterations after dam construction. These species also offered an excellent opportunity for future monitoring, since they indicate the direction in which ecological change is taking place. Detector species, which span in a wide range of conditions, may be useful indicators of changes produced by anthropogenic activities; actually, they were successfully used in evaluation of forest degradation of African savanna (McGeoch et al., 2002).

In this study we found a marked reduction in total algal abundance at the downstream site after dam construction during the low water period. On the other hand, richness was higher after dam construction at the downstream site during the high water period, while diversity increased after dam construction. Even when richness and diversity were higher at the downstream site before dam construction (Amaidén, 2008), three-way ANOVAs clearly showed how their value increased after dam construction. As has been observed, the impacts of a disturbance on diatom species richness are unpredictable and vary according to the type of stressors involved (Stevenson, 1984a). Thus, Wu et al. (2009) found that diatom richness was higher at upstream sites after dam construction. They explained these results by a release of sediments downstream of the dam, which have negative

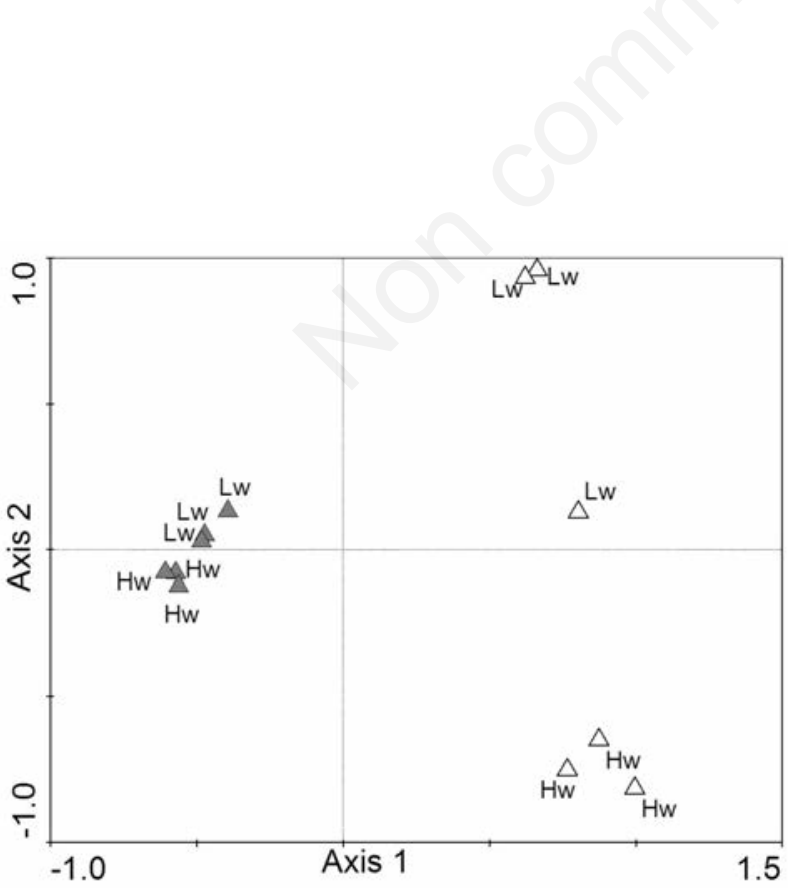

Fig. 4. CA of periphyton samples (166 species) taken at the downstream site before (open symbols) and after (filled symbols) dam construction during high (Hw) and low water (Lw) periods. effects on algal community. However, Wu et al. (2010) observed that richness and density in regulated reaches were higher than the expected for non-regulated reaches, which may be explained by a favorable combination of biotic interactions and habitat changes. Thomson et al. (2005) indicated that diatom species richness downstream of a dam decreased after dam removal. These different responses to flow regulation may be explained by the pattern of disturbance and the degree of alteration in current velocity. Hydrologic regime alteration and disturbance pattern may be important factors in determining assemblages present in the study area. Thus, disturbance becomes the main source of temporal and spatial heterogeneity affecting the structure and dynamics of natural communities and it is a natural selection agent in the evolution of life story traits (Sousa, 1984).

The CA performed with downstream samples before and after dam construction showed that there would be a loss of seasonality at the downstream site since assemblages were more similar between hydrological periods after dam construction. Similar changes in the hydrologic regime and the small variation between periods have been reported (Magilligan et al., 2003; Gomes Lopes et al., 2004; Magilligan and Nislow, 2005; Poff and Zimmerman, 2010). Moreover, the CA performed with samples taken after dam construction showed a clear segregation of sites. It also evidenced the homogenizing effect of the dam since a low separation of samples from each hydrological period

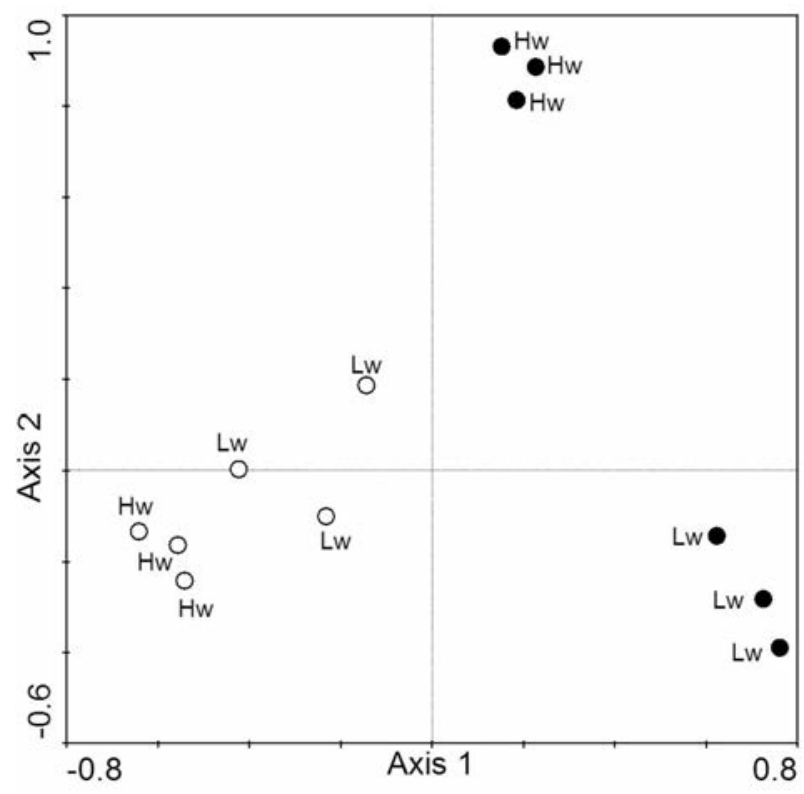

Fig. 5. CA of periphyton samples (173 species) taken at upstream (filled symbols) and downstream (open symbols) sites during high $(\mathrm{Hw})$ and low water $(\mathrm{Lw})$ periods after dam construction. 
Tab. 5. List of indicator taxa from sites upstream (A) and downstream (B) of the dam. Taxa with significant $(\mathrm{P}<0.05)$ indicator value (IV) $>70 \%$ were selected.

\begin{tabular}{|c|c|c|c|c|c|c|c|c|c|}
\hline & Taxa & IV & $\mathrm{pH}$ & Conductivity & TS & Current & Life form & Salt content & N. Het. \\
\hline Site A & Epithemia turgida (Ehrenb.) Kütz. & 99.7 & $\mathrm{AL}$ & & & LMB & BENT & & \\
\hline \multirow[t]{12}{*}{ Upstream } & Epithemia sorex Kütz. & 99.5 & $\mathrm{AL}$ & $\mathrm{H}$ & $\mathrm{EU}$ & & BENT & & \\
\hline & Gomphonema dichotomum Kütz. & 99.4 & $\mathrm{CMN}$ & & & & BENT & & \\
\hline & Scenedesmus cells & 98.9 & & & & & PLA & & \\
\hline & Epithemia adnata (Kütz.) Bréb. & 97.9 & & M & & & BENT & & \\
\hline & $\begin{array}{l}\text { Rhopalodia gibba var. ventricosa (Kütz.) } \\
\text { Perag. and M. Perag. }\end{array}$ & 97.6 & & $\mathrm{M}-\mathrm{H}$ & & & BENT & & \\
\hline & Fragilaria crotonensis Kitton & 83.2 & IN-AL & & EU-ME & $\mathrm{L}$ & PLA & IND & \\
\hline & Nitzschia tubicola Grun. & 81.8 & & & & & BENT & & \\
\hline & $\begin{array}{l}\text { Cocconeis placentula var. lineata } \\
\text { (Ehrenb.) van Heurck }\end{array}$ & 80.7 & CMN-AL-ALI & & EU & $\mathrm{L}$ & BENT & IND & \\
\hline & $\begin{array}{l}\text { Cocconeis placentula var. euglypta } \\
\text { (Ehrenb.) Grun. }\end{array}$ & 80.4 & CMN-AL-AL & & EU & $\mathrm{L}$ & BENT & IND & \\
\hline & Encyonema minutum (Hilse) D.G. Mann & 79.8 & CMN-AL & & ME & & BENT & OLI & \\
\hline & Cocconeis pediculus Ehrenb. & 78.8 & AL & & ME-EU & & BENT & IND & \\
\hline & $\begin{array}{l}\text { Ankistrodesmus fusiformis Corda } \\
\text { sensu Korsch }\end{array}$ & 76.3 & & & & & PLA & & \\
\hline \multirow[t]{22}{*}{$\begin{array}{l}\text { Site B } \\
\text { Downstream }\end{array}$} & $\begin{array}{l}\text { Gyrosigma obtusatum (Sull and Wormley) } \\
\text { Boyer }\end{array}$ & 100.0 & CMN-AL-ALI & & EU & $\mathrm{L}$ & BENT & & \\
\hline & $\begin{array}{l}\text { Pinnularia silviasalae Metzeltin, } \\
\text { Lange-Bert and García-Rodríguez }\end{array}$ & 100.0 & & & & & BENT & & \\
\hline & Sellaphora pupula (Kütz) Mereschk. & 100.0 & CMN-AL & & & & BENT & HAL & \\
\hline & Navicula gregaria Donkin & 99.9 & $\mathrm{AL}$ & & EU & & BENT & & \\
\hline & Amphora perpusilla Grun. & 94.7 & AL & & & & BENT & & \\
\hline & Gomphonema parvulum (Kütz.) Kütz. & 94.5 & & & EU-SP & $\mathrm{R}$ & BENT & & NH \\
\hline & Achnanthidium exiguum (Grun.) Czarn. & 94.0 & $\mathrm{AL}$ & & & $\mathrm{L}$ & BENT & & \\
\hline & $\begin{array}{l}\text { Planothidium lanceolatum (Bréb.) } \\
\text { Round and Bukht. }\end{array}$ & 93.0 & CMN-AL & & OL-EU & $\mathrm{R}$ & BENT & & \\
\hline & Amphipleura lindheimeri Grun. & 92.7 & $\mathrm{AL}$ & & SP & & BENT & IND & \\
\hline & Achnanthes $\mathrm{sp}_{3}$ & 91.3 & & & & & BENT & & \\
\hline & Rhoicosphenia curvata (Kütz.) Grun. & 90.8 & $\mathrm{AL}$ & & EU & ROB & BENT & OLI & \\
\hline & $\begin{array}{l}\text { Amphora ovalis var. affinis (Kütz.) } \\
\text { van Heurck }\end{array}$ & 85.1 & ALB & & & $\mathrm{R}$ & BENT & & \\
\hline & $\begin{array}{l}\text { Geissleria decussis (Østrup) Lange-Bert. } \\
\text { and Metzeltin }\end{array}$ & 85.1 & AL & & & & BENT & & \\
\hline & $\begin{array}{l}\text { Achnanthes lanceolata var. frequentissima } \\
\text { Lange-Bert. }\end{array}$ & 83.3 & & & & & BENT & & \\
\hline & Gomphonema minutum (Agardh) Agardh & 83.3 & & & EU & & BENT & & \\
\hline & $\begin{array}{l}\text { Navicula elginensis var. neglecta (Krasske) } \\
\text { Patrick }\end{array}$ & 83.3 & $\mathrm{AL}$ & & EU & & BENT & & \\
\hline & Pinnularia microstauron (Ehrenb.) Cleve & 83.3 & IN-AL & & OL-ME & $\mathrm{L}$ & BENT & & \\
\hline & Neidium affine (Ehrenb) Pfitz. & 83.3 & IN-AL-ALB & & & $\mathrm{R}$ & BENT & & \\
\hline & Nitzschia amphibia Grun. & 80.9 & AL & & EU & & BENT & & $\mathrm{NH}$ \\
\hline & Navicula cryptotenella Lange-Bert. & 80.0 & CMN-AL & & & & BENT & OLI-IND & \\
\hline & Scenedesmus quadricauda Chod. & 78.9 & & & EU & & PLA & & \\
\hline & Amphora submontana Hust. & 72.6 & ALB & & & ROB & BENT & OLI & \\
\hline
\end{tabular}

Ecological attributes extracted from Hustedt (1930), Patrick and Reimer (1966), Fore and Grafe (2002), Oliva Martínez et al., (2005), Lane and Brown (2007) are presented.

TS, trophic state; N.Het., nitrogen heterotrophic; CMN, circumneutral; IN, indifferent; AL, alkaliphilous; ALB, alkalibiontic; H, high; M, medium; SP, saprobous; EU, eutraphentic; ME, mesotraphentic; OL, oligotraphentic; LMB, limnobiontic; L, limnophil; R, Reophil; ROB, reobiontic; BENT, benthic; PLA, planktonic; IND, indifferent; OLI, oligohalobe; HAL, Halophil; NH, nitrogen heterotrophic. 
was observed in the downstream site. This result is reinforced by the fact that current velocity was similar between high and low water periods at the downstream site, unlike upstream of the dam. Current velocity has been reported as one of the main factors that determine taxa distribution and abundance in regulated streams (Horner and Welch, 1981; Stevenson, 1984b; Reiter and Carlson, 1986; Growns, 1999; Poff et al., 2007; Poff and Zimmerman, 2010). Differences in aquatic biota between sites upstream and downstream of dams similar to those found in our study have been reported by many researchers (Jakob et al., 2003; Uehlinger et al., 2003; Poff and Zimmerman, 2010). Particularly for algal assemblages, Growns (1999) found that differences in diatom communities upstream and downstream of dams were greater than the differences between sites of unregulated streams. Further, Growns and Growns (2001) and Chester and Norris (2006) found changes in the periphytic community downstream of dams similar to those observed in this study.

The presence of alkaliphilous indicator species at the upstream site coincided with the greater $\mathrm{pH}$ values recorded there. At the downstream site, nutrients were higher and, coincidently, there were species that thrive in nutrient-enriched water. Marcus (1980) recorded a greater algal growth downstream of a dam, which was attributed to nitrogen discharges from the reservoir. Particularly, the presence in our study of Nitszchia amphibia and Gomphonema parvulum as indicators of the downstream site agree with Marcus's (1980) results since these species are nitrogen heterotrophic, preferring organic compounds as a source of nitrogen and growing best in the presence of nitrates (Patrick, 1977). Further studies that evaluate alterations in nutrient dynamic by the dam would allow establishing the cause-effect relationships between nutrient concentration and the presence of species that thrive in nutrient-enriched water. Some other indicator species at our downstream site were planktonic, which is in agreement with Ward and Stanford's (1983b) statement in relation to the presence of planktonic organisms downstream of dams. These authors stated that surfacerelease impoundments release planktonic organisms occurring only in the lower reaches of river systems, except below impoundments and natural lakes. Plankton is also released from deep-release dams, as the dam of this study, but not in great numbers.

In this study, as predicted, we found that proportional abundance of early-successional species was higher at the upstream site, while proportion of late-successional species was higher at the downstream site. Molloy (1992), Stevenson (1996), Passy (2007) and Wu et al. (2009) reported that under conditions of high current velocity, similar to those occurring in the upstream site of our study, there is a predominance of prostrate and erect forms, best adapted to withstanding or recovering from disturbance.
At downstream sites, however, centric and stalked forms are highly abundant since they can be attached in small free spaces. In our study site, lower fluctuations in discharge downstream of the dam may have favored succession advance and may have allowed the development of a complex community. At the upstream site, mainly during the high water period, floods may have caused sloughing of life forms from the outer layers of the biofilm, thus resetting the algal community to early successional stages, as in Oemke and Burton (1986), Peterson and Stevenson (1992) and Peterson (1996). McCormick and Stevenson (1991) and Stevenson et al. (1991) proposed that, during succession, benthic algal dominance change from species with high immigration abilities or disturbance resistant, such as Cocconeis spp., to species that predominate with limiting resources and high population densities, such as stalked species. In lotic ecosystems, where the spatial heterogeneity shaped by the current maintains a patch dynamics (Townsend, 1989) and temporal variation in the discharge produces periodical disturbances, the life forms of early and late-successional species represent ecological viable strategies. Under such conditions, disturbance variation in frequency and intensity may strongly affect successional patterns, dominance hierarchies and species diversity (Peterson and Stevenson, 1992).

Total abundance was higher at the upstream site dur-

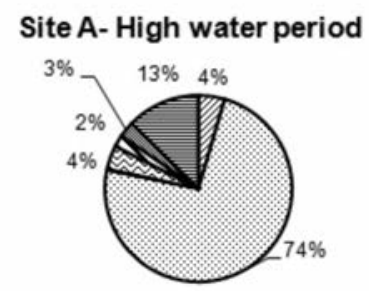

Site A- Low water period

Site B- High water period

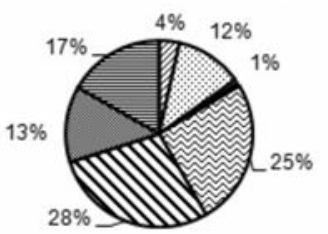

Site B- Low water period
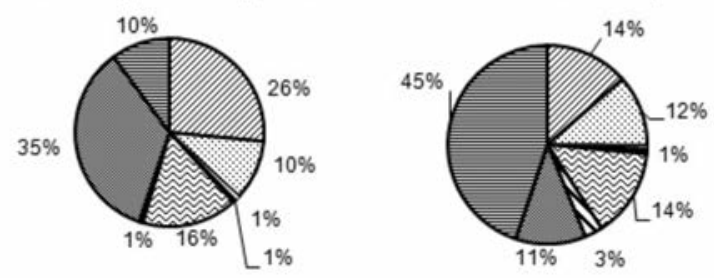

口Achnanthes spp. $\quad$ Cocconeis spp. $\square$ Centric

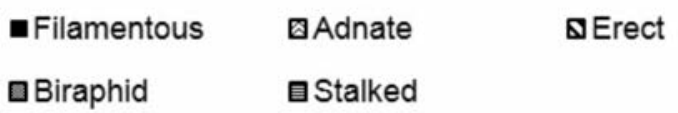

Fig. 6. Proportion of diatom morphological guilds present at sites upstream (A) and downstream (B) of the dam differentiated by hydrological period. 
ing the low water period whereas biomass did not show significant differences between sites. In contrast, some authors found higher values of biomass in reaches downstream of dams (Marcus, 1980; Uehlinger et al., 2003). The decrease in abundance in our site downstream of the dam may have been related to a higher deposition or release of sediments from the reservoir during the low water period (Wu et al., 2009). According to Wood and Armitage (1997) a reduction in current velocity, particularly during the low water period, can lead to a deposition of large volumes of sediments and decaying organic matter onto the river bed. Fine sediment suspension and deposition affect producers in many ways, mainly by reducing the penetration of light and, as a result, reducing photosynthesis and primary productivity within the stream; also, by causing the sloughing and preventing attachment to the substrate of algal cells (Wood and Armitage, 1997).

Contrary to what we expected, at the downstream site, species richness was higher in resemblance to that observed by Wu et al. (2010). The dominance of Cocconeis placentula var. euglypta and C. placentula var. lineata at the upstream site during the high water period led to a lower value of richness in that site. This dominance may be explained by the growth form of these species that allows them to withstand higher current velocities. Additionally, the effect of grazers which remove the outer layers of periphyton mat (Wellnitz et al., 1996) could be important in our site (Orpella, 2008). Grazers can reduce algal biomass and influence community composition by eliminating certain species and growth forms (Steinman, 1996; Rosemond et al., 2000; Díaz Villanueva and Albariño, 2003; Díaz Villanueva et al., 2004; Álvarez and Peckarsky, 2005).

Diversity and evenness indices were also higher downstream of the dam during the high water period. A similar pattern was reported by Marcus (1980), who explained the rise in algal growth and diversity as due to the increase in nutrient discharge from the impoundment that creates a more favorable environment for diatoms. Similarly, increases in macroinvertebrate richness and diversity were recorded downstream of small dams as due to the absence of important habitat alterations (Principe, 2010). Stenger-Kovács et al. (2006) found that hydromorphological modifications increased downstream diversity in many river-types. However, Ward and Stanford (1983b), Ward (1992), Jakob et al. (2003) and Poff and Zimmerman (2010) proposed that biodiversity downstream of dams tends to be lower than in natural streams due to a reduced temporal heterogeneity in temperature and flow regime, and to the elimination of sensitive species responding to habitat alteration. Nevertheless, in this study downstream conditions may have exhibited an intermediate level of disturbance (Ward and Stanford, 1983a; Sousa, 1984) in comparison with the upstream site,
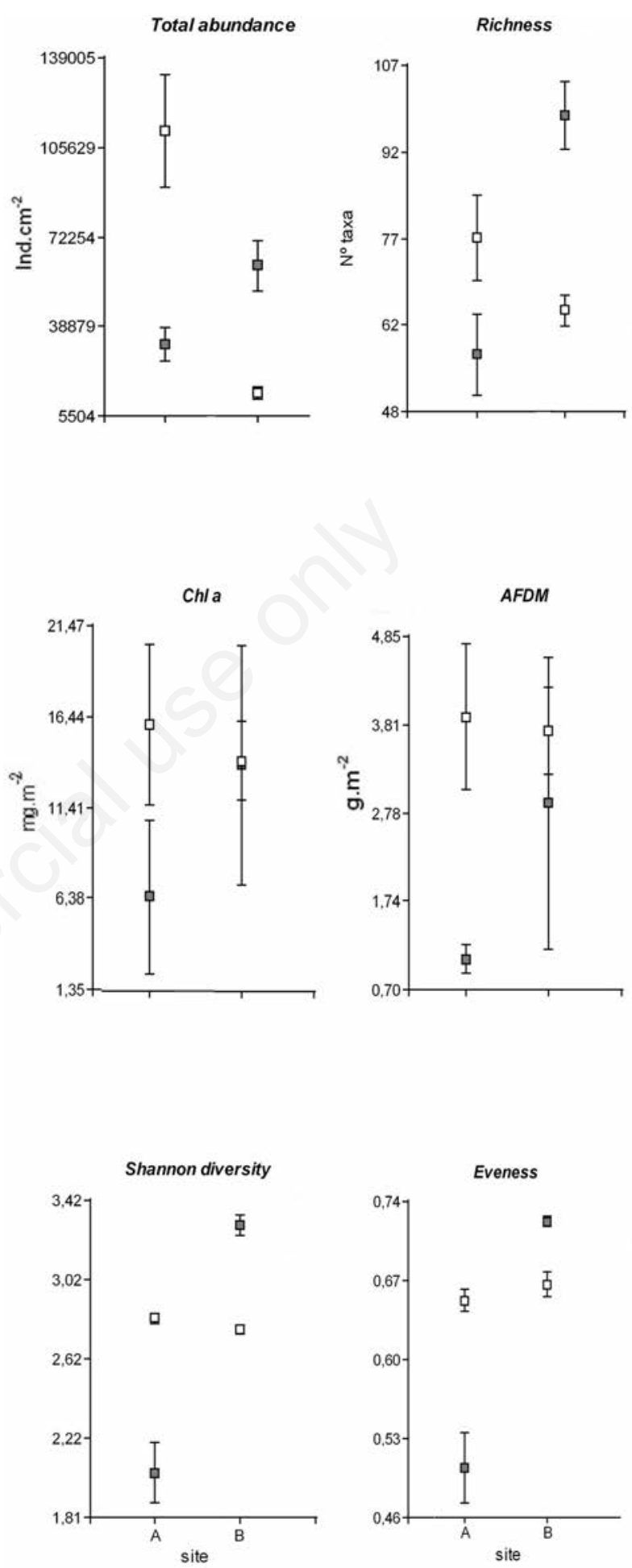

High water Low water

Fig. 7. Point with SD bars plots of structural and biomass variables obtained at sites upstream (A) and downstream (B) of the dam during high and low water periods after dam construction. 
where sloughing by current could be higher, only Cocconeis spp. staying attached. According to Sousa (1984) regional diversity is the greatest at intermediate levels of disturbance; at higher rates of disturbance most patches are dominated by early-successional species while at lower rates of disturbance late-successional species predominate. In addition, many factors can affect algal diversity in streams, which may interact with current velocity, such us light, grazing or nutrients. Both sites present a similar riparian cover, so light would not be an important factor in determining diversity patterns. Before dam construction, greater densities of Ephemeroptera were recorded upstream of the dam (Orpella, 2008), being these insects the main grazers in these mountain streams. Currently, there are no records of density changes of these grazers after dam construction, but future research may elucidate if the effect of grazing is different between upstream and downstream sites. In relation to nutrients, some variations in their concentration or availability may be affecting the downstream community since some studies have already reported an important effect of nutrients in regulated reaches (Ward and Stanford, 1983b; Marcus, 1980; Uehlinger et al., 2003).

In conclusion, the dam altered algal community composition and structure and favored succession advance since it reduced current velocity and flow fluctuations. However, considering that diversity was higher after dam construction and at the downstream site, unlike predicted, some other factors may be affecting the community, such as nutrient concentrations, sedimentation or grazing. Further research is necessary to explain the dam effects on algal colonization dynamics, grazing, nutrient availability and substrate stability, as well as to test the usefulness of detector species for monitoring river systems.

\section{ACKNOWLEDGMENTS}

This study was financially supported by Secretaría de Ciencia y Técnica (UNRC). We thank M.E. Luque and A. Amaidén for laboratory and field assistance and C. Cibils for figure processing.

The authors would like to thank the two anonymous reviewers for their valuable comments and suggestions.

\section{REFERENCES}

Allan JD, Castillo MM, 2007. Stream ecology: structure and function of running waters, $2^{\text {nd }}$ ed. Springer: $436 \mathrm{pp}$.

Alvarez M, Peckarsky BL, 2005. How do grazers affect periphyton heterogeneity in streams? Oecologia 142:576-587.

Amaidén MA, 2008. Distribución del perifiton en un arroyo serrano, p. 1-41. Tesis de Licenciatura, Dpto. de Ciencias Naturales, UNRC.

Battarbee EW, 1986. Diatom analysis, p. 527-570. In: B.E. Berglund (ed.) Handbook of Holocene Palaeoecology and Palaeohydrology. J. Wiley and Sons, New York.
Biggs BJF, Kilroy C, 2000. Stream periphyton monitoring manual. NIWA Publ. for the New Zealand Ministry for the Environment.

Biondini ME, Mielke PW Jr., Berry KJ, 1988. Data-dependent permutation techniques for the analysis of ecological data. Vegetatio 75:161-168.

Brandt SA, 2000. Classification of geomorphological effects downstream of dams. Catena 40:375-401.

Cabido D, Cabido M, Garre SM, Gorgas JA, Miatello R, Rambaldi S, Ravelo A, Tassile JL, 2003. Regiones Naturales de la Provincia de Córdoba. Serie C, Publicaciones Técnicas, Agencia Córdoba, Dirección de Ambiente, Córdoba.

Cavalier-Smith T, 1998. A revised six-kingdom system of life. Biol. Rev. Camb. Philos. Soc. 73:203-266.

Caviglia ML, 2002. Hidrología ambiental: Relación entre geología- calidad del agua superficial/ subterránea y grado de antropización de la Cuenca del arroyo Achiras- Del Gato, Provincia de Córdoba, Argentina, p. 1-139. Tesis de Licenciatura, Dpto de Geología, UNRC.

Chester H, Norris R, 2006. Dams and flow in the Cotter River, Australia: effects on instream trophic structure and benthic metabolism. Hydrobiologia 572:275-286.

Corigliano MC, 1994. El efecto de los embalses sobre la fauna planctónica y bentónica del río Ctalamochita (Tercero), (Córdoba, Argentina). Revista UNRC 14:23-38.

Degiovanni S, 2005. Análisis de problemas geoambientales vinculados a los recursos hídricos en la Cuenca del arroyo Achiras- del Gato. Características climáticas, geológicogeomorfológicas y de ocupación territorial, p. 181-189. In: M. Blarasin, S. Degiovanni, A. Cabrera and M. Villegas (eds.) Aguas Superficiales y Subterráneas en el Sur de Córdoba: Una Perspectiva Geoambiental. Ed. UNRC, Río Cuarto, Córdoba.

Di Rienzo JA, Casanoves F, Balzarini MG, Gonzalez L, Tablada M, Robledo CW, 2011. InfoStat versión 2011. Grupo InfoStat, FCA, Universidad Nacional de Córdoba, Argentina.

DIPAS, 2001. Estudio Ambiental preliminar para el proyecto: Presa de Achiras, p. 1-37. Provincia de Córdoba, Departamento de Recursos Hídricos.

Díaz Villanueva V, Albariño R, 2003. Algal ingestion and digestion by two ephemeropteran larvae from a Patagonian Andean stream, p. 468-475. In: E. Gaino (ed.) Research update on Ephemeroptera and Plecoptera. University of Perugia, Italy.

Díaz Villanueva V, Albariño R, Modenutti B, 2004. Grazing impact of two aquatic invertebrates on periphyton from an Andean-Patagonian stream. Arch. Hydrobiol. 159:455-471.

Doffo N, Degiovanni S, Origlia D, 2005. Análisis de las causas y procesos involucrados en el deterioro de las obras hidráulicas situadas en la cuenca media de los arroyos del Gato y Las Lajas, Córdoba, p. 223-233. In: M. Blarasin, S. Degiovanni, A. Cabrera and m. Villegas (eds.) Aguas Superficiales y Subterráneas en el Sur de Córdoba: Una Perspectiva Geoambiental. Ed. UNRC, Río Cuarto, Córdoba.

Dufrêne M, Legendre P, 1997. Species assemblages and indicators species: the need for a flexible assymetrical approach. Ecol. Monogr. 67:345-366.

Evans JE, Huxley JM, Vincent RK, 2007. Upstream channel changes following dam construction and removal using a GIS/remote sensing approach. J. Am. Water Resour. Assoc. 43:683-697. 
Fore LS, Grafe C, 2002. Using diatoms to assess the biological condition of large rivers in Idaho (USA). Freshwat. Biol. 47:2015-2037.

Francoeur SN, Biggs BJF, 2006. Short term effects of elevated velocity and sediment abrasion on benthic algal communities. Hydrobiologia 561:59-69.

Gomes Lopes LF, Antunes Do Carmo JS, Vitor Cortes RM, Oliveira D, 2004. Hydrodynamics and water quality modelling in a regulated river segment: application on the instream flow definition. Ecol. Model. 173:197-218.

Griffith MB, Hill BH, McCormick FH, Kaufmann PR, Herlihy AT, Selle AR, 2005. Comparative application of indices of biotic integrity based on periphyton, macroinvertebrates, and fish to southern Rocky Mountain streams. Ecol. Indic. 5:117-136.

Growns I, 1999. Is genus or species identification of periphytic diatoms required to determine the impacts of river regulation? J. Appl. Phycol. 11:273-283.

Growns IO, Growns JE, 2001. Ecological effects of flow regulation on macroinvertebrate and periphytic diatom assemblages in the Hawkesbury - Nepean River, Australia. Regul. River. 17:275-293.

Grubbs SA, Taylor JM, 2004. The influence of flow impoundment and river regulation on the distribution of riverine macroinvertebrates at Mammoth Cave National Park, Kentucky, USA. Hydrobiologia 520:19-28.

Hardwick GG, Blinn DW, Usher HD, 1992. Epiphytic diatoms on Cladophora glomerata in the Colorado River, Arizona: longitudinal and vertical distribution in a regulated river. Southwest. Nat. 37:148-156.

Hasle GR, 1978. Some specific preparations: diatoms, p. 136142. In: A. Sournia (ed.) Phytoplankton manual, UNESCO.

Hauer FR, Lorang MS, 2004. River regulation, decline of ecological resources, and potential for restoration in a semi-arid lands river in the western USA. Aquat. Sci. 66:388-401.

Hill BH, Herlihy AT, Kaufmann PR, Stevenson RJ, McCormick FH, Johnson CB, 2000. Use of periphyton assemblage data as an index of biotic integrity. J. N. Am. Benthol. Soc. 19:50-67.

Hill BH, Stevenson RJ, Pan Y, Herlihy AT, Kaufmann PR, Johnson $\mathrm{CB}, 2001$. Comparison of correlations between environmental characteristics and stream diatom assemblages characterized at genus and species levels. J. N. Am. Benthol. Soc. 202:299-310.

Horner RR, Welch EB, 1981. Stream periphyton development in relation to current velocity and nutrients. Can. J. Fish. Aquat. Sci. 38:449-457.

Hustedt F, 1930. Die Süsswasser-flora mitteleuropas, Heft 10: Bacillariophyta (Diatomeas), $2^{\text {nd }}$ ed. Jena, Germany: 465 pp.

Jakob C, Robinson CT, Uehlinger U, 2003. Longitudinal effects of experimental floods on stream benthos downstream from a large dam. Aquat. Sci. 65:223-231.

Kawamura T, Hirano R, 1992. Seasonal changes in benthic diatom communities colonizing glass slides in Aburtsubo Bay, Japan. Diatom Res. 7:227-239.

Kingsford RT, 2000. Ecological impacts of dams, water diversions and river management on floodplain wetlands in Australia. Austral Ecol. 25:109-127.

Lane CR, Brown MT, 2007. Diatoms as indicators of isolated herbaceous wetland condition in Florida, USA. Ecol. Indic. 7:521-540.
Lewis LA, McCourt RM, 2004. Green algae and the origin of land plants. Am. J. Bot. 91:1535-1556.

Lobo EA, Callegaro VLM, Hermany G, Bes D, Wetzel CA, Oliveira MA, 2004. Use of epilithic diatoms as bioindicators from lotic systems in southern Brazil, with special emphasis on eutrophication. Acta Limnol. Bras. 16:25-40.

Luti R, Bertran MA, Galera FM, Müller N, Berzal M, Nores M, Herrera MA, Barrera JC, 1979. Vegetación, p. 318-321. In: J.V. Vázquez, R.A. Miatello and M.E. Roqué (eds.), Geografía Física de la Provincia de Córdoba. Boldt Ed., Buenos Aires.

Magilligan FJ, Nislow KH, 2005. Changes in hydrologic regime by dams. Geomorphology 71:61-78.

Magilligan FJ, Nislow KH, Graber BE, 2003. Scale-independent assessment of discharge reduction and riparian disconnectivity following flow regulation by dams. Geology 31:569-572.

Marcus MD, 1980. Periphytic community response to chronic nutrient enrichment by a reservoir discharge. Ecology 61:387-399.

McCormick PV, Stevenson RJ, 1991. Mechanisms of benthic algal succession in lotic environments. Ecology 72:1835-1848.

McCune B, Grace JB, 2002. Analysis of Ecological Communities. MjM Software, Oregon.

McCune B, Mefford MJ, 1999. Multivariate Analysis of Ecological Data, Version 5.0. MjM Software, Gleneden Beach.

McGeoch MA, van Rensburg BJ, Botes A, 2002. The verification and application of bioindicators: a case study of dung beetles in a savanna ecosystem. J. Appl. Ecol. 39:661- 672.

Merritt DM, Cooper DJ, 2000. Riparian vegetation and channel change in response to river regulation: a comparative study of regulated and unregulated streams in the Green River Basin, USA. Regul. River. 16:543-564.

Molloy JM, 1992. Diatom communities along stream longitudinal gradients. Freshwat. Biol. 28:59-69.

Newcomb TJ, Hanna KM, Anderson MR, 2001. Macroinvertebrate forage in the Smith River Tailwater: Feast or Famine? Proc. Annu. Conf. SEAFWA 55:116-125.

Nichols S, Norris R, Maher W, Thoms M, 2006. Ecological effects of serial impoundment on the Cotter River, Australia. Hydrobiologia 572:255-273.

Norris RH, Thoms MC, 1999. What is river health? Freshwat. Biol. 41:197-209.

Nusch EA, 1980. Comparison of different methods for chlorophyll and phaeopigment determination. Arch. Hydrobiol. 14:14-36.

Oemke MP, Burton TM, 1986. Diatom colonization dynamics in a lotic system. Hydrobiologia 139:153-166.

Olden JD, Naiman RJ, 2010. Incorporating thermal regimes into environmental flows assessments: modifying dam operations to restore freshwater ecosystem integrity. Freshwat. Biol. 55:86-107.

Oliva Martínez MG, Ramírez Martínez JG, Garduño Solórzano G, Cañetas Ortega J, Ortega MM, 2005. Caracterización diatomológica en tres cuerpos de agua de los humedales de Jilotepec-Ixtlahuaca, Estado de México. Hidrobiologica (Iztapalapa) 15:1-26.

Orpella GH, 2008. Estructura y diversidad del ensamble bentónico del arroyo Achiras en tramos de ritron. Tesis de Licenciatura, Dpto. de Ciencias Naturales, UNRC.

Passy SI, 2007. Diatom ecological guilds display distinct and 
predictable behaviour along nutrient and disturbance gradients in running waters. Aquat. Bot. 86:171-178.

Patrick R, 1977. Ecology of freshwater diatoms-Diatom communities, p. 1-498. In: D. Werner (ed.) The Biology of Diatoms, Botanical Monographs 13. University of California Press, Berkeley and Los Angeles.

Patrick R, Reimer CW, 1966. The Diatoms of the United States exclusive of Alaska and Hawai, volume 1. Monographs of the Academy of Natural Sciences of Philadelphia 13.

Peterson CG, 1996. Response of periphyton communities to natural physical disturbance, p. 375-402. In: R.J. Stevenson, M.L. Bothwell and R.L. Lowe (eds.) Algal ecology: freshwater benthic ecosystems. Academic Press, Inc., San Diego.

Peterson CG, Stevenson RJ, 1992. Resistance and resilience of lotic algal communities: Importance of disturbance timing and current. Ecology 73:1445-1461.

Poff NL, Hart DD, 2002. How dams vary and why it matters for the emerging science of dam removal. Bioscience 52:659-668.

Poff NL, Zimmerman JKH, 2010. Ecological responses to altered flow regimes: a literature review to inform the science and management of environmental flows. Freshwat. Biol. 55:194-205.

Poff NL, Olden JD, Merritt DM, Pepin DM, 2007. Homogenization of regional river dynamics by dams and global biodiversity implications. Proc. Natl Acad. Sci. USA 104:5732-5737.

Poff NL, Allan JD, Bain MB, Karr JR, Prestegaard KL, Richter BD, Sparks RE, Stromberg JC, 1997. The natural flow regime: a paradigm for river conservation and restoration. Bioscience 47:769-784.

Principe RE, 2010. Ecological effects of small dams on benthic macroinvertebrate communities of mountain streams (Córdoba, Argentina). Ann. Limnol. 46:1-15.

Reiter MA, Carlson RE, 1986. Current velocity in streams and composition of benthic algal mats. Can. J. Fish. Aquat. Sci. 43:1156-1162.

Rosemond AD, Mulholland PJ, Brawley SH, 2000. Seasonally shifting limitation of stream periphyton: response of algal populations and assemblage biomass and productivity to variation in light, nutrients and herbivores. Can. J. Fish. Aquat. Sci. 57:66-75.

Sousa WP, 1984. The role of disturbance in natural communities. Annu. Rev. Ecol. Syst. 15:353-391.

Steinman AD, 1996. Effects of grazers on benthic freshwater algae, p. 341-373. In: R.J. Stevenson, M.L. Bothwell and R.L. Lowe (eds.) Algal ecology: freshwater benthic ecosystems. Academic Press, Inc., San Diego.

Stenger-Kovács C, Padisák J, Soróczki-Pintér É, Ács É, Borics G, Buczkó K, van Dam H, 2006. The effect of hydromorphological modifications of streamflow compositional features of attached diatom assemblages in Hungarian streams. p. $139-145$ in Proc. $6^{\text {th }}$ Int. Symp. on Use of Algae for monitoring rivers, Balatonfüred, Hungary.

Stevenson RJ, 1984a. Epilithic and epipelic diatoms in the Sandusky River, with emphasis on species diversity and water quality. Hydrobiologia 114:161-175.

Stevenson RJ, 1984b. How currents on different sides of substrates in streams affect mechanisms of benthic algal accumulation. Int. Rev. Ges. Hydrobiol. 69:241-262.

Stevenson RJ, 1996. The stimulation and drag of current, p. 321340. In: R.J. Stevenson, M.L. Bothwell and R.L. Lowe (eds.)
Algal ecology: freshwater benthic ecosystems. Academic Press, Inc., San Diego.

Stevenson RJ, Bahls LL, 1999. Periphyton protocols, p. 1-23. In: M.T. Barbour, J. Gerritsen, B.D. Snyder and J.B. Stribling (eds.), Rapid bioassessment protocols for use in streams and wadeable rivers: periphyton, benthic macroinvertebrates and fish, $2^{\text {nd }}$ ed. U.S. Environmental Protection Agency, Office of Water, Washington, DC.

Stevenson RJ, Smol JP, 2002. Use of algae in environmental assessment, p. 775-804. In: J.D. Wehr and R.G. Sheath (eds.) Freshwater algae of North America: ecology and cassification. Academic Press, New York.

Stevenson RJ, Peterson CG, Kirschtel DB, King CC, Tuchman NC, 1991. Density-dependent growth, ecological strategies, and effects of nutrients and shading on benthic diatom succession in streams. J. Phycol. 27:59-69.

Stoermer EF, Kreis RG Jr, Andresen NA, 1999. Checklist of diatoms from the Laurentian Great lakes. II. J. Great Lakes Res. 25:515-566.

ter Braak CJF, Šmilauer P, 1997-2002. CANOCO for Windows version 4.5. Biometris- plant Research International. Wageningen, The Netherlands.

ter Braak CJF, Šmilauer P, 1998. CANOCO Reference Manual and User's Guide to Canoco for Windows: Software for Canonical Community Ordination (version 4). Microcomputer Power, Ithaca, NY, USA.

Thomson JR, Hart DD, Charles DF, TL, Nightengale, Winter DM, 2005. Effects of removal of a small dam on downstream macroinvertebrate and algal assemblages in a Pennsylvania stream. J. N. Am. Benthol. Soc. 24:192-207.

Townsend CR, 1989. The patch dynamics concept of stream community ecology. J. N. Am. Benthol. Soc. 8:36-50.

Uehlinger U, Kawecka B, Robinson CT, 2003. Effects of experimental floods on periphyton and stream metabolism below a high dam in the Swiss Alps (River Spöl). Aquat. Sci. 65:199-209.

Underwood AJ, 1994. Spatial and temporal problems with monitoring, p. 182-204. In: P. Calow and G. Petts (eds.) The Handbook of River. Blackwell, Oxford.

Vallania AE, Corigliano MC, 2007. The effect of regulation caused by a dam on the distribution of the functional feeding groups of the benthos in the sub basin of the Grande River (San Luis, Argentina). Environ. Monit. Assess. 124:201-209.

Vannote RL, Minshall GW, Cummins KW, Sedell JR, Cushing CE, 1980. The river continuum concept. Can. J. Fish. Aquat. Sci. 37:130-137.

Villafañe VE, Reid FMH, 1995. Métodos de microscopía para la cuantificación del fitoplancton, p. 169-185. In: K. Alveal, M.E. Ferrario, E.C. Oliveira and E. Sar (eds.) Manual de Métodos Ficológicos, Universidad de Concepción, Chile.

Ward JV, 1992. Aquatic Insect Ecology - Biology and Habitat. Wiley and Sons, New York: 438 pp.

Ward JV, Stanford JA, 1979. The Ecology of Regulated Streams. New York, Plenum Press.

Ward JV, Stanford JA, 1983a. The intermediate disturbance hypothesis: an explanation for biotic diversity patterns in lotic ecosystems, p. 347-356. In: T.D. Fontaine and S.M. Bartell (eds.) Dynamics of lotic ecosystems. Ann Arbor Science Publishers, Ann Arbor, Michigan.

Ward JV, Stanford JA, 1983b. The serial discontinuity concept 
of lotic ecosystems, p. 29-42. In: T.D. Fontaine and S.M. Bartell (eds.) Dynamics of lotic ecosystems. Ann Arbor Science Publishers, Ann Arbor, Michigan.

Wellnitz TA, Rader R, Ward JV, 1996. Light and a grazing mayfly shape periphyton in a Rocky Mountain stream. J. N. Am. Benthol. Soc. 15:496-507.

Wood PJ, Armitage PD, 1997. Biological effects of fine sediment in the lotic environment. Environ. Manage. 21:203-217.

Wu N, Tang T, Zhou SC, Jia XH, Li DF, Liu RQ, Cai QH, 2009.
Changes in benthic algal communities following construction of a run-of-river dam. J. N. Am. Benthol. Soc. 28:69-79.

Wu N, Tang T, Fu X, Jiang W, Li F, Zhou S, Cai Q, Fohrer N, 2010. Impacts of cascade run-of-river dams on benthic diatoms in the Xiangxi River, China. Aquat. Sci. 72:117-125.

Wunsam S, Cattaneo A, Bourassa N, 2002. Comparing diatom species, genera and size in biomonitoring: a case study from streams in the Laurentians (Québec, Canada). Freshwat. Biol. 47:325-340. 